\title{
Pengaruh Karakteristik Calon Wakif dalam Keputusan Berwakaf Uang
}

\author{
Prameswara Samofa Nadya ${ }^{1}$, Muhammad Iqbal ${ }^{2}$ \\ 1), 2) Perbanas Institute Jakarta, Indonesia \\ Email: prameswara.samofa@perbanas.id
}

\begin{abstract}
Abstrak:
Penelitian ini bertujuan mengidentifikasi faktor-faktor yang mempengaruhi pengetahuan dan keputusan seseorang berwakaf uang, yang hasilnya dapat dimanfaatkan untuk menyusun sasaran strategi penghimpunan dana wakaf uang. Pendekatan yang dipakai dengan cara mengidentifikasi faktor-faktor karakteristik masyarakat Indonesia. Target khusus yang ingin dicapai meliputi strategi pemasaran yang meliputi segmentasi calon wakif (orang yang berwakaf) sehingga ada skala prioritas penghimpunan dana wakaf uang yang mempertimbangkan perilaku dan karakteristik masyarakat baik yang bersifat geografis, demografis maupun psikografis. Metode yang digunakan kuantitatif dengan teknik probability sampling dalam menggumpulkan data. Teknik yang digunakan untuk analisis data adalah regresi logit dan uji beda koefisien kontigensi. Usia, pendidikan dan keaktifan dalam kajian keislaman merupakan faktor utama karakteristik individu yang mempengaruhi seseorang untuk berwakaf uang. Pendidikan yang semakin tinggi, usia yang semakin matang serta semakin banyaknya aktivitas yang dilakukan untuk menuntut ilmu agama menghasilkan pemahaman yang semakin tinggi. Tingginya pemahaman terhadap wakaf uang dapat menjadi landasan untuk mendorong masyarakat berperan serta aktif dalam penghimpunan dana wakaf uang.
\end{abstract}

Kata kunci: wakaf uang; wakif; usia; pendidikan; pengetahuan

This study aims to identify the factors that influence the knowledge and decisions of a person with cash waqf, the results of which can be used to develop a strategic goal for collecting cash waqf funds. The approach used is by identifying the characteristic factors of Indonesian society. Specific targets to be achieved include a marketing strategy that includes the segmentation of wakif candidates (people with waqf) so that there is a priority scale for collecting cash waqf funds that takes into account the behavior and characteristics of the community, both geographic, demographic and psychographic. The method used is quantitative with probability sampling techniques in collecting data. The technique used for data analysis is logit regression and contingency coefficient difference test. Age, education and activeness in Islamic studies are the main factors in individual characteristics that influence someone to donate cash waqf. Higher education, more mature age and more activities undertaken to study religion resulted in higher understanding. A high level of understanding of cash waqf can be the basis for encouraging people to participate actively in collecting cash waqf funds.

Keywords: cash waqf; wakif; age; education; knowledge

http://ejournal.iainmadura.ac.id/index.php/iqtishadia

DOI: 10.1905/iqtishadia.v8i2.4177 


\section{PENDAHULUAN}

Wakaf telah memerankan peran yang penting dalam pengembangan sosial, ekonomi dan budaya masyarakat (Hasanah, 2012). Hal ini dimungkinkan apabila wakaf digunakan sebagai salah satu instrumen pemberdayaan ekonomi umat, bukan hanya sebagai aset yang memiliki nilai ibadah tetapi tidak memiliki nilai secara sosial dan ekonomi. Pemberdayaan wakaf produktif sudah ada sejak zaman Rasulullah SAW dan masa kejayaan Islam. Menurut Hasanah (2012), wakaf uang sudah ada sejak zaman Dinasti Mamluk, meskipun para ahli fikih memperdebatkan boleh atau tidaknya uang diwakafkan. Termasuk di Indonesia, meskipun di berbagai negara wakaf uang sudah lama dipraktikkan dan diatur dalam undang-undang namun bagi mayoritas umat Islam wakaf hanya sebatas pada bentuk tanah atau harta yang digunakan untuk aktivitas keagamaan semata. Sebagian masyarakat di Indonesia masih menempatkan harta wakaf pada hal yang bersifat diam daripada yang menghasilkan atau produktif (Kasdi, 2016).

Wakaf produktif sendiri telah dituangkan dalam Undang-undang No. 41 Tahun 2004 tentang wakaf. Undang-undang tersebut antara lain menjelaskan tentang wakaf uang sebagai salah satu opsi bagi masyarakat yang ingin berwakaf meskipun dengan dana yang minim. Sebelumnya Majelis Ulama Indonesia (MUI) juga telah mengeluarkan fatwa tentang wakaf uang pada tanggal 11 Mei 2002 tetang bolehnya wakaf uang dan surat berharga lainnya.

Potensi wakaf uang setiap tahunnya dapat mencapai lebih dari 100 triliun rupiah, dengan realisasi sampai dengan akhir tahun 2018 sudah mencapai 400 miliar rupiah. Data terakhir menunjukkan bahwa potensi wakaf uang di Indonesia mencapai 300 triliun dengan realisasi yang baru mencapai sekitar 500 miliar (Lubis, 2020). Hal ini mengindikasikan masih besarnya kesenjangan yang tinggi antara potensi yang ada dengan realisasi penghimpunan dana wakaf uang dari masyarakat.

Rendahnya partisipasi masyarakat dalam program wakaf uang disebabkan oleh banyak hal, mulai dari kurangnya informasi tentang wakaf uang (Adeyemi, Ismail \& Hassan, 2016a; Fanani, 2011; Ilyas, 2014), pengetahuan dan pemahaman tentang wakaf uang (Adeyemi et al., 2016; Dahlan, 2015), kondisi sosial budaya (Adeyemi et al., 2016), rendahnya kompetensi nazhir sebagai pengelola wakaf (Fanani, 2011), hingga kurangnya peran pemerintah dalam menggalakan program wakaf uang (Siswantoro \& Rosdiana, 2016). Selain itu, beberapa lembaga yang ditunjuk dalam menghimpun wakaf uang juga belum optimal dalam menghimpun dana masyarakat (Furqon, 2011).

Optimalisasi penghimpunan dana wakaf uang akan dapat dilakukan manakala ada suatu strategi yang terencana dengan baik. Bukan sekedar sosialisasi dan edukasi tentang wakaf uang saja yang perlu dilakukan, tetapi juga diperlukan adanya suatu usaha memasarkan program wakaf uang dengan strategi pemasaran yang tepat. Melihat kondisi masyarakat Indonesia yang sangat heterogen, dibutuhkan strategi khusus dalam memasarkan program wakaf uang. Diversifikasi terhadap program pemasaran juga harus dilakukan dengan mepertimbangkan karakteristik masyarakat Indonesia. Salah satu cara mendiversifikasi program pemasaran dengan cara melihat segmentasi masyarakat dari sisi geografis, demografi dan psikografis.

Segmentasi yang diartikan sebagai pengelompokan individu dalam aspek geografis, demografis dan psikografis berguna dalam menyusun program pemasaran yang tepat kepada konsumen, dalam hal wakaf uang kepada calon wakif. Aspek geografis meliputi geografis wilayah, ukuran kota, kepadatan dan iklim. Sedangkan aspek demografis terdiri dari usia, ukuran keluarga, siklus hidup keluarga, jenis kelamin, penghasilan, pekerjaan, pendidikan agama, ras, generasi, kewarganegaran dan kelas sosial. Aspek psikografis sendiri meliputi 
psikografis gaya hidup, kepribadian, perilaku kejadian, manfaat, status pemakai, tingkat pemakaian, status kesetiaan, tahap kesiapan pembeli dan sikap terhadap produk (Kotler \& Keller, 2015).

Secara demografis, karakteristik individu berpengaruh terhadap pengetahuan dan pemahaman seseorang terhadap wakaf uang. Pendidikan merupakan faktor yang paling mempengaruhi pemahaman seseorang terhadap wakaf uang (Efrizon, 2008; Yunimar, 2015). Selain pendidikan, ada beberapa karakteristik demografi yang diduga berpengaruh terhadap pengetahuan dan pemahaman seseorang tentang wakaf, seperti usia, pendapatan, dan pekerjaan. Atas dasar inilah diduga bahwa pengetahuan dan pemahaman seseorang tentang wakaf uang berbeda dari sisi karakteristik usia, pendapatan dan pekerjaan.

Selain karakteristik demografis masyarakat, diduga karakteristik geografis individu ikut menentukan kesuksesan program wakaf. Sistem informasi geografis dibutuhkan dalam rangka penggelolaan dan monitoring penyebaran asset wakaf (Fahmi \& Sugiarto, 2016). Selain itu, tingkat religiusitas seseorang juga mempengaruhi minat mendonasikan sebagian hartanya pada aktivitas sosial berdimensi keagamaan (Satrio \& Siswantoro, 2016).

Ruang lingkup penelitian terbatas pada penghimpunan dana wakaf uang dari masyarakat. Batasan objek penelitian juga pada wakaf uang saja. Hasil penelitian ini diharapkan dapat berguna bagi para penghimpun dana wakaf tunai agar dapat mengidentifikasi faktor-faktor yang mempengaruhi kesadaran dan keputusan masyarakat untuk menjadi wakif. Sehingga selain dapat mensegmentasikan masyarakat yang potensial untuk menjadi wakif, lembaga-lembaga tersebut juga dapat menyusun program marketing penghimpunan dana wakaf uang sesuai hasil penelitian.

Efrizon (2008) juga menemukan bahwa persepsi masyarakat akan wakaf uang dipengaruhi oleh tingkat pendidikan, akses terhadap media informasi, pemahaman hukum Islam dan keterlibatan masyarakat dalam organisasi sosial keagamaan. Semakin tinggi pendidikan seseorang maka semakin besar peluangnya paham mengenai wakaf tunai. Begitu pula dengan pemahaman hukum Islam yang taklid akan menyebabkan kecilnya peluang masyarakat untuk memahami wakaf uang secara benar. Sedangkan jika seseorang jarang mengakses media informasi tentang wakaf uang, maka semakin kecil peluang untuk memahami wakaf uang itu sendiri.

Penelitian ini merupakan sebuah langkah dalam merancang sebuah pendekatan atau strategi yang efektif dalam menghimpun dana wakaf uang. Rancangan ini terfokus pada kegiatan pengidentifikasian faktor demografis, psikografis dan geografis apa saja yang dapat menentukan pengetahuan dan keputusan masyarakat Indonesia untuk berwakaf uang.

Adapun manfaat yang diharapan dari penelitian ini ada dua, yaitu secara teoritis dan secara manajerial. Secara teoritis, hasil dari penelitian dapat menjadi salah satu referensi dalam membangun strategi pemasaran yang efektif terhadap wakaf uang sebagai salah satu bentuk aktivitas finaltropi Islam. Hasil ini diharapkan memberikan paradigma baru dalam mensosialisasikan aktivitas finaltropi yang bersifat sosial bukan konsumtif. Secara manajerial hasil dari penelitian ini diharapkan dapat bermanfaat bagi pemangku kepentingan untuk memilih atribut-atribut yang cocok bagi masyarakat untuk menerima program wakaf tunai sehingga sosialisasi yang dilakukan untuk program tersebut dapat lebih efektif dan efisien. Kedepannya para pemangku kepentingan seperti Badan Wakaf Indonesia (BWI), Nazhir (seperti Lembaga Amil Zakat dan Wakaf) dan Departemen Agama dapat lebih memfokuskan aktifitas sosialisasi pada atribut yang dianggap menentukan dalam menumbuhkan pengetahuan dan keputusan dalam berwakaf uang. 


\section{METODE PENELITIAN}

Penelitian ini menggunakan desain kuantitatif yang merupakan penelitian sistematis terhadap bagian-bagian dan fenomena serta hubungan-hubungannya (McMillan \& Schumacher, 2009). Tujuan penelitian kuantitatif mengembangkan dan menggunakan modelmodel, teori-teori dan atau hipotesis yang berkaitan dengan fenomena alam. Proses pengukuran adalah bagian yang sentral dalam penelitian kuantitatif karena memberikan hubungan yang fundamental antara pengamatan empiris dan ekspresi matematis dari hubungan-hubungan kuantitatif (Creswell, 2013).

Variabel penelitian meliputi karakteristik individu masyarakat (geografis, demografis dan psikografis). Aspek geografis meliputi geografis wilayah dan ukuran kota, sedangkan aspek demografis terdiri dari usia, ukuran keluarga, siklus hidup keluarga, jenis kelamin, penghasilan, pekerjaan, pendidikan dan generasi. Aspek psikografis meliputi gaya hidup, kepribadian, status pemakai, tingkat pemakaian, kesetiaan, tahap kesiapan pembeli dan sikap terhadap produk. Instrumen kuesioner menggunakan pertanyaan tertutup yang terdiri atas serangkaian pertanyaan yang digunakan untuk mendapatkan data mengenai variabelvariabel penelitian. Pengukuran atas pertanyaan pada kuesioner menggunakan skala likert.

Jenis data penelitian merupakan data primer dengan objek penelitian umat Islam di Indonesia. Data dikumpulkan dengan menggunakan instrumen kuesioner. Teknik sampling menggunakan probability sampling yang bisa ditentukan besarnya dari jumlah populasi yang telah diketahui. Pemilihan sampel dengan teknik ini berdasarkan atas penilaian peneliti bahwa responden adalah pihak yang paling baik untuk dijadikan sampel penelitiannya (Sekaran \& Bougie, 2013). Sampel terdiri dari 310 responden yang tersebar di 20 provinsi dengan 3 provinsi utama, yaitu DKI Jakarta, Jawa Barat dan Banten.

Teknik analisis data yang digunakan pada penelitian ini lebih menekankan pada analisis statistik, seperti regresi logistik. Regresi logistik atau yang biasa dikenal dengan binary logistic digunakan untuk menganalisis pengaruh variabel bebas terhadap variabel terikat dengan variabel terikatnya berbentuk kategori. Selain regresi logistik sebagai alternatif metode yang digunakan adalah uji beda koefisien kontijensi. Uji beda koefisien kontijensi ditujukan untuk melihat ada tidaknya perbedaan antar karakteristik individu masyarakat dalam hal kesadaran dan keputusan untuk berwakaf uang. Hasil uji beda nantinya akan digunakan untuk membuktikan hipotesis penelitian satu sampai tiga. Dengan mengetahui ada tidaknya perbedaan antar karakteristik maka dapat diidentifikasi pengaruh karakteristik tersebut terhadap kesadaran dan keputusan untuk berwakaf uang.

\section{HASIL DAN PEMBAHASAN}

Secara geografis sebaran responden terpusat pada tiga provinsi di pulau Jawa, yaitu Jawa Barat, DKI Jakarta, dan Banten. Jika ditotal ketiga provinsi tersebut menyumbang sampel hingga 78,1\%. Sedangkan sebaran responden yang berada di pulau Jawa mencapai 86,1\%, sisanya menyebar pada pulau Sumatera, Kalimantan, dan Sulawesi. Hanya 1\% yang berada di keempat pulau tersebut. Gambar 1, mendeskripsikan sebaran responden berdasarkan pulau-pulau yang ada di Indonesia. 


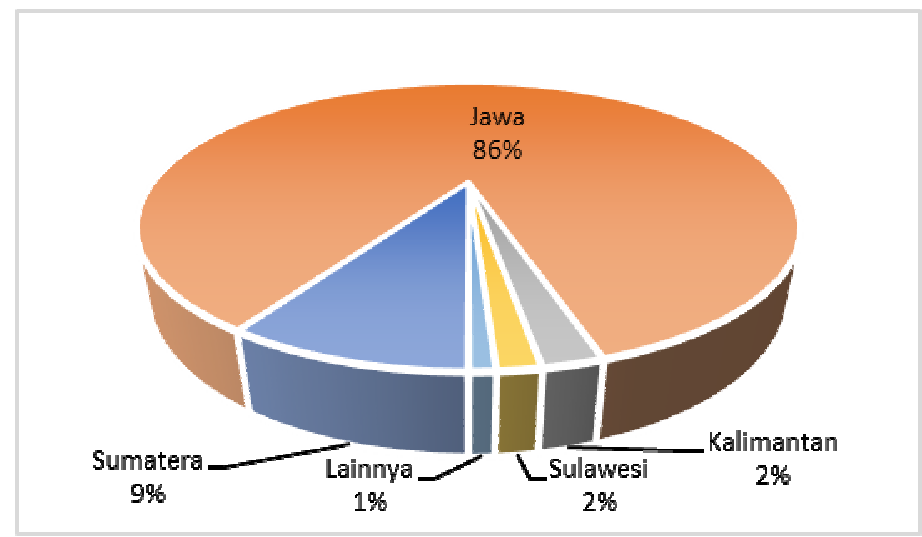

\section{Gambar 1 \\ Sebaran Responden Berdasarkan Pulau}

Aspek demografi meliputi jenis kelamin, usia, pendidikan, pekerjaan, penghasilan, status pernikahan, jumlah anggota keluarga dan status anggota keluarga. Sedangkan aspek psikografi dari responden meliputi keaktifan mengikuti kajian keislaman, seberapa besar pengaruh ulama yang dijadikan panutan serta aktifitas berzakat responden.

Secara umum, responden penelitian didominasi oleh perempuan dan dari sisi usia, sebarannya cukup merata, mulai dari usia 17 sampai dengan di atas 60 tahun. Lebih dari 90 persen responden berusia dari 17 sampai 50 tahun, yang berusia di atas 50 tahun hanya 9,4 persen. Pendidikan responden juga didominasi oleh lulusan sarjana dan pascasarjana yang jumlahnya hingga 77,4 persen sedangkan sisanya hanya lulusan diploma, SMA dan sederajatnya. Pekerjaan utama responden adalah pegawai swasta, guru/dosen, PNS dan wiraswasta dengan rata-rata penghasilan 3 sampai 10 juta rupiah. Lebih dari 70 persen responden telah berkeluarga dengan status kebanyakan sebagai kepala keluarga dan istri. Rata-rata jumlah anggota keluarga dari para responden berjumlah 3 sampai 5 orang dengan kecenderungan jumlah anggota keluarga yang kecil. Sebagaimana terlihat dari jumlah anggota keluarga yang hanya 1 sampai 2 orang mencapai 44,4 persen. Rangkuman demografi responden disajikan pada Tabel 1.

Tabel 1

Deskripsi Demografi Responden

\begin{tabular}{llc}
\hline \multicolumn{1}{c}{ Karakteristik } & \multicolumn{1}{c}{ Kategori } & Persentase \\
\hline Jenis Kelamin & Wanita & $57.1 \%$ \\
& Pria & $42.9 \%$ \\
Usia & $17-25$ tahun & $21.9 \%$ \\
& $26-35$ tahun & $27.7 \%$ \\
& $36-50$ tahun & $41.0 \%$ \\
& $51-60$ tahun & $8.4 \%$ \\
Pendidikan & $>60$ tahun & $1.0 \%$ \\
& SMA dan sederajatnya & $13.9 \%$ \\
& Diploma & $8.7 \%$ \\
& Sarjana (S1) & $44.2 \%$
\end{tabular}




\begin{tabular}{llr} 
& Pascasarjana (S2 \& S3) & $33.2 \%$ \\
Pekerjaan & Pelajar/Mahasiswa & $9.4 \%$ \\
& Pegawai Negeri Sipil & $8.1 \%$ \\
& Wiraswasta & $38.4 \%$ \\
& Guru/Dosen & $8.4 \%$ \\
& Pedagang & $21.3 \%$ \\
& Profesional & $2.3 \%$ \\
& Ibu Rumah Tangga & $5.2 \%$ \\
Penghasilan & Lainnya & $5.5 \%$ \\
& $<3$ juta & $1.6 \%$ \\
& 3 - 5 juta & $21.7 \%$ \\
& 5 - 10 juta & $31.3 \%$ \\
& 10 - 20 juta & $30.0 \%$ \\
& 20 - 30 juta & $9.7 \%$ \\
30 - 50 juta & $3.7 \%$ \\
& $>50$ juta & $2.3 \%$ \\
& 1 - 2 orang & $1.3 \%$ \\
& 3 - 5 orang & $44.4 \%$ \\
Stamlah Anggota Keluarga & 6 - 10 orang & $47.2 \%$ \\
& Kepala Keluarga & $8.3 \%$ \\
& Istri & $36.4 \%$ \\
& Anak & $34.4 \%$ \\
& Bapak/Ibu Kandung/Mertua & $22.6 \%$ \\
Saudara & $5.2 \%$ \\
& & $1.3 \%$ \\
\hline
\end{tabular}

Sumber: data diolah (2020)

Dari semua responden yang mengisi kuesioner, ternyata tidak sampai setengahnya pernah menunaikan wakaf. Tidak seperti aktivitas berzakat yang sudah menjadi kebiasaan mereka. Hampir 90 persen responden rutin membayar zakat, tetapi hanya 38 persen saja yang pernah berwakaf. Kebanyakan dari mereka yang berwakaf memandang bahwa wakaf itu merupakan salah satu bentuk shadaqah jariyah, yaitu satu dari tiga amalan yang tidak akan terputus pahalanya walaupun orang tersebut telah tiada, sebagaimana hadits berikut ini:

Dari Abu Hurairah ra., sesungguhnya Rasulullah SAW bersabda, "Apabila anak Adam (manusia) meninggal dunia, maka putuslah amalnya, kecuali tiga perkara: shadaqah jariyah, ilmu yang bermanfaat dan anak saleh yang mendo'akan orang tuannya." (HR. Muslim)

Bagi mereka yang belum pernah berwakaf memiliki berbagai alasan, tetapi alasan yang utama adalah karena tidak memiliki sesuatu yang dapat diwakafkan, baik itu berupa tanah, uang atau harta benda lainnya. Walaupun demikian, mereka yang belum pernah berwakaf memiliki keinginan untuk berwakaf. Lebih dari 95\% ingin berwakaf dengan 66,1\% sangat ingin dan selebihnya ingin dengan berbagai pertimbangan. 
Secara umum pemahaman responden terhadap wakaf relatif baik, hal ini ditunjukkan dari hasil jawaban responden tentang hukum wakaf. Lebih dari $73 \%$ menyatakan bahwa wakaf itu sunnah dan hanya $8 \%$ yang menjawab mubah, sedangkan sisanya malah mewajibkan (fardu). Rincian tetang aktivitas berwakaf dituangkan dalam Tabel 2.

Tabel 2

Deskripsi Aktivitas Berwakaf

\begin{tabular}{llc}
\hline \multicolumn{1}{c}{ Karakteristik } & \multicolumn{1}{c}{ Kategori } & Persentase \\
\hline Pernah Berwakaf & Tidak & $61.9 \%$ \\
& Ya & $38.1 \%$ \\
& Mendapat tawaran untuk berwakaf & $15.9 \%$ \\
& (termasuk iklan) & $61.6 \%$ \\
& Karena ingin bershadaqah jariyah & $9.4 \%$ \\
& Direkomendasikan oleh teman/kerabat & \\
& Sudah menjadi tradisi/kebiasaan & $11.6 \%$ \\
Alasan belum pernah & keluarga/ lingkuangan/ komunitas/ & \\
Berwakaf & pengajian & $1.4 \%$ \\
& Lainnya & $61.3 \%$ \\
& Belum punya sesuatu untuk diwakafkan & $17.8 \%$ \\
& Tidak mengetahui mekanisme wakaf & $2.5 \%$ \\
& Tidak bisa karena suatu keadaan & $16.6 \%$ \\
& Belum ada kesempatan untuk berwakaf & $0.6 \%$ \\
& Wakaf bukan sesuatu yang wajib & $1.2 \%$ \\
& Latihan & $66.1 \%$ \\
Keinginan Berwakaf & Sangat ingin & $29.2 \%$ \\
& Ingin dengan berbagai pertimbangan & $3.6 \%$ \\
& Biasa saja & $0.5 \%$ \\
& Ragu-ragu & $7.7 \%$ \\
& Fardhu 'ain & $9.7 \%$ \\
& Fardhu kifayah & $61.0 \%$ \\
& Sunnah muakkad & $12.9 \%$ \\
& Sunnah ghairu muakkad & $8.7 \%$ \\
\hline
\end{tabular}

Sumber: data diolah (2020)

Walaupun kurang dari setengahnya $(38,1 \%)$ responden yang pernah berwakaf, tetapi lebih dari setengah responden (51,6\%) mengetahui tentang wakaf uang, di mana pengetahuan yang mereka dapatkan tentang wakaf uang sebagaian besar diperoleh dari bangku sekolah atau perguruan tinggi. Selain itu, informasi tentang wakaf uang juga diperoleh dari alim ulama dan tokoh masyarakat, lembaga amil zakat dan iklan media elektronik. Persepsi masyarakat tentang wakaf uang masih berfokus pada berwakaf dalam bentuk uang tunai, tanpa mengetahui peruntukannya kemana. Tapi ada juga dari masayrakat 
yang menganggap bahwa wakaf uang itu merupakan wakaf yang memang disalurkan untuk aktivitas yang produktif.

Hampir semua yang mengetahui wakaf uang menyatakan bahwa wakaf uang dibolehkan $(96,9 \%)$. Mereka yakin bahwa wakaf itu boleh dalam bentuk apapun, termasuk dalam bentuk uang. Selain itu, mereka juga meyakini hukum dibolehkannya wakaf uang karena sudah ada ijma ulamanya. Meskipun menyakini bahwa wakaf uang itu boleh, ternyata hanya 56,1\% yang menyatakan pernah berwakaf uang. Angka ini tidak jauh berbeda dengan mereka yang pernah berwakaf, sehingga jika ditotal dari seluruh responden hanya sekitar $25 \%$ yang pernah berwakaf uang sedangakn sisanya belum pernah berwakaf uang. Rangkuman deskripsi responden tentang aktivitas berwakaf uang dapat dilihat pada Tabel 3. Disitu juga dijelaskan bahwa responden berwakaf uang pada berbagai lembaga amil zakat dan sejenisnya yang relatif menyebar merata.

Tabel 3

Deskripsi Aktivitas Berwakaf Uang

\begin{tabular}{|c|c|c|}
\hline Karakteristik & Kategori & Persentase \\
\hline \multirow{2}{*}{$\begin{array}{l}\text { Pengetahuan tentang } \\
\text { Wakaf Uang }\end{array}$} & Tidak & $48.4 \%$ \\
\hline & $\mathrm{Ya}$ & $51.6 \%$ \\
\hline \multirow{8}{*}{$\begin{array}{l}\text { Sumber Informasi Wakaf } \\
\text { Uang }\end{array}$} & Iklan di media cetak & $7.8 \%$ \\
\hline & Iklan di media elektronik & $15.7 \%$ \\
\hline & Alim ulama atau tokoh masyarakat & $18.1 \%$ \\
\hline & Saudara/kerabat & $8.9 \%$ \\
\hline & Lembaga Amil Zakat & $16.7 \%$ \\
\hline & Pembelajaran di Kampus/Sekolah & $23.1 \%$ \\
\hline & Brosur & $7.5 \%$ \\
\hline & Lainnya & $2.1 \%$ \\
\hline \multirow[t]{4}{*}{ Persepsi Wakaf Uang } & $\begin{array}{l}\text { Wakaf secara langsung kepada } \\
\text { penerima manfaatnya }\end{array}$ & $15.5 \%$ \\
\hline & Wakaf dalam bentuk uang tunai & $50.6 \%$ \\
\hline & Wakaf untuk aktifitas yang produktif & $32.7 \%$ \\
\hline & Lainnya & $1.2 \%$ \\
\hline \multirow{2}{*}{$\begin{array}{l}\text { Hukum Kebolehan Wakaf } \\
\text { Uang }\end{array}$} & Tidak & $3.1 \%$ \\
\hline & Ya & $96.9 \%$ \\
\hline \multirow[t]{5}{*}{$\begin{array}{l}\text { Alasan Wakaf Uang } \\
\text { dibolehkan }\end{array}$} & $\begin{array}{l}\text { Karena wakaf dapat berbentuk } \\
\text { apapun }\end{array}$ & $44.6 \%$ \\
\hline & Sudah mendapat ijma ulamanya & $35.2 \%$ \\
\hline & Sudah ada di UU & $9.9 \%$ \\
\hline & Sunnah Rasul & $9.4 \%$ \\
\hline & Lainnya & $0.9 \%$ \\
\hline \multirow{3}{*}{$\begin{array}{l}\text { Alasan Wakaf Uang tidak } \\
\text { dibolehkan }\end{array}$} & Bentuk wakaf uang tidak lazim & $14.3 \%$ \\
\hline & $\begin{array}{l}\text { Wakaf hanya boleh dalam bentuk } \\
\text { tanah dan bangunan }\end{array}$ & $28.6 \%$ \\
\hline & Objek wakaf harus bersifat abadi & $42.9 \%$ \\
\hline
\end{tabular}


Tidak pernah dicontohkan oleh Rasul dan Sahabat

Tidak

Pernah Berwakaf Uang

Ya

$43.9 \%$

$56.1 \%$

Dompet Dhuafa

$20.4 \%$

$4.9 \%$

$3.9 \%$

$1.0 \%$

Baitul Maal Hidayatullah

$4.9 \%$

Tabung Wakaf

$18.4 \%$

Lembaga Keuangan Syariah

$46.6 \%$

Sumber: data diolah (2020)

Keputusan wakif memiliki skor dengan kritetia sangat tinggi. Kontribusi terbesar penyusun variabel keputusan ada pada indikator keyakinan wakif bahwa wakaf uang alternatif sedekah yang baik. Sebagai mana diketahui bahwa wakaf merupakan bentuk sedekah yang pahalanya tidak akan pernah putus walaupun si wakif telah tiada. Selain itu, kemudahan wakaf uang dibandingkan wakaf lain menjadikan indikator ini sebagai alasan terbesar seseorang mau berwakaf uang.

Pada penelitian ini digunakan dua pendekatan, yaitu metode Regresi Logit atau Logistik Biner dan Koefisien Kontigensi. Penggunaan metode regresi logit (Binary Logistic) bertujuan mengindentifikasi aspek-aspek demografis dan psikografis masyarakat dalam mempengaruhi pengetahuan tentang wakaf uang dan keputusan berwakaf baik wakaf secara umum maupun wakaf uang secara khusus. Penggunaan metode regresi logit membutuhkan beberapa prasyarat sebelum dilakukan analisis terhadap hasil akhirnya. Prasyarat itu biasa disebut dengan evaluasi hasil yang meliputi penilaian seberapa baik (goodness of fit) model regresi dan uji signifikansi menyeluruh (overall model fit). Goodness of fit model regresi logit seperti yang terlihat pada Tabel 4 ada dua nilai yang digunakan, yaitu Cox \& Snell $R$ Square dan Nagelkerke $R$ Square. Hasil keduanya relatif kecil untuk setiap model. Hal ini mengindikasikan bahwa variabel-variabel bebas yang dipilih dalam setiap model untuk menjelaskan variabel terikatnya tidak cukup kuat, dimana rata-rata hanya $10 \%$. Hanya model ketiga saja dengan variabel terikat keputusan wakaf uang yang memiliki nilai Nagelkerke $R^{2}$ mencapai $18 \%$. Hal ini mengidikasikan bahwa variabel-variabel bebas yang mengukur aspek demografi dan psikografi mampu menjelaskan perilaku seseorang dalam memutuskan berwakaf uang atau tidaknya hanya sebesar 18 persen. Sedangkan sisanya 82 persen dijelaskan oleh variabel lainnya diluar model ketiga.

Tabel 4 Goodness of Fit Binary Logistic

\begin{tabular}{lcc}
\hline \multicolumn{1}{c}{ Model (dependent variable) } & $\begin{array}{c}\text { Cox \& Snell } R \\
\text { Square }\end{array}$ & $\begin{array}{c}\text { Nagelkerke } \\
\text { R Square }\end{array}$ \\
\hline $\begin{array}{l}\text { Model I } \\
\text { (Pengetahuan Wakaf Uang) }\end{array}$ & 0.091 & 0.121
\end{tabular}


Model II

(Keputusan Berwakaf)

0.175

Model III

(Keputusan Berwakaf Uang)

0.133

0.180

Sumber: data diolah (2020)

Overall model fit meliputi Omnibus test dan Hosmer \& Lemeshow test. Seperti pada Tabel 5, terlihat bahwa nilai signifikansi chi square Omnibus test semuanya lebih kecil dari 0,05 yang artinya variabel-variabel bebas dalam model mempengaruhi variabel terikatnya atau dengan kata lain, model yang disusun (baik model I, II ataupun III) layak digunakan untuk menjelaskan pengaruh variabel bebas terhadap variabel terikat. Sedangkan untuk nilai signifikasi chi square Hosmer \& Lemeshow test semuanya lebih besar dari 0,05. Hal ini menunjukkan bahwa uji chi square tidak signifikan maka probabilitas yang diprediksi (dalam hal ini adalah pegetahuan tentang wakaf uang, keputusan berwakaf, dan keputusan berwakaf uang) sesuai dengan probabilitas yang diobservasi. Artinya, model regresi logit yang dibentuk sesuai dengan data yang ada atau dengan kata lain, model dapat menjelaskan pengaruh variabel bebas terhadap variabel terikatnya.

Tabel 5

Overall Model Fit Binary Logistic

\begin{tabular}{lcccc}
\hline \multicolumn{1}{c}{ Model (dependent variable) } & $\begin{array}{c}\text { Omnibus } \\
\text { Test }\end{array}$ & Sig. & $\begin{array}{c}\text { Hosmer \& } \\
\text { Lemeshow } \\
\text { Test }\end{array}$ & Sig. \\
\hline $\begin{array}{l}\text { Model I } \\
\text { (Pengetahuan Wakaf Uang) }\end{array}$ & 26.691 & 0.001 & 9.836 & 0.277 \\
$\begin{array}{l}\text { Model II } \\
\text { (Keputusan Berwakaf) }\end{array}$ & 38.806 & 0.000 & 13.112 & 0.108 \\
$\begin{array}{l}\text { Model III } \\
\text { (Keputusan Berwakaf Uang) }\end{array}$ & 19.823 & 0.011 & 9.836 & 0.277 \\
\hline
\end{tabular}

Sumber: data diolah (2020)

Setelah dilakukan uji kebaikan model (goodness of fit) dan kelayakan model (overall model fit) dari ketiga model yang ada, dimana hasil yang diperoleh memenuhi standar yang berlaku, maka tahap terakhir dalam evaluasi model regresi logit adalah melakukan uji signifikansi (significance test). Hasil uji signifikansi ada pada Tabel 6 yang melibatkan delapan variabel bebas dan tiga variabel terikat. Delapan variabel bebas tersebut antara lain: jenis kelamin, usia, pendidikan, penghasilan, jumlah anggota keluarga, frekuensi menghadiri kajian, pengaruh ulama panutan dan keaktivan dalam berzakat.

Pada model pertama, terlihat bahwa hanya variabel pendidikan saja yang memiliki nilai signifikansi kurang dari 0,05. Hal ini menunjukkan bahwa pendidikan mempengaruhi pengetahuan seseorang terhadap wakaf uang. Nilai koefisien variabel pendidikan yang bertanda positif menunjukkan bahwa semakin tinggi tingkat pendidikan seseorang maka orang tersebut semakin mengetahui adanya wakaf uang dan sebaliknya, semakin rendah pendidikan seseorang maka orang tersebut semakin tidak mengetahui adanya wakaf uang.

Jika pada model pertama hanya ada satu variabel bebas saja yang berpengaruh terhadap variabel terikat, berbeda dengan model kedua yang variabel terikatnya keputusan

Iqtishadia: Jurnal Ekonomi dan Perbankan Syariah

171

Vol. 8 No. 2 Desember 2021 
berwakaf. Pada model kedua selain pendidikan yang mempengaruhi seseorang memutuskan untuk berwakaf, jumlah anggota keluarga juga mempengaruhi seseorang untuk berwakaf. Sama dengan pengaruh pendidikan terhadap pengetahuan wakaf uang, pengaruh pendidikan terhadap keputusan berwakaf juga berpengaruh positif atau berbanding lurus. Sedangkan jumlah anggota keluarga juga berpengaruh positif terhadap keputusan seseorang untuk berwakaf. Semakin banyak anggota keluarga seseorang maka kemungkinan orang tersebut untuk berwakaf semakin tinggi, dan sebaliknya.

Tabel 6 Significance Test Regresi Binary Logistic

\begin{tabular}{|c|c|c|c|c|c|c|}
\hline \multirow[t]{2}{*}{ Karakteristik } & \multicolumn{2}{|c|}{$\begin{array}{l}\text { Pengetahuan } \\
\text { Wakaf Uang }\end{array}$} & \multicolumn{2}{|c|}{$\begin{array}{c}\text { Keputusan } \\
\text { Berwakaf }\end{array}$} & \multicolumn{2}{|c|}{$\begin{array}{c}\text { Keputusan } \\
\text { Berwakaf Uang }\end{array}$} \\
\hline & B & Sig. & B & Sig. & B & Sig. \\
\hline $\mathrm{JK}$ & 0.372 & 0.166 & -0.189 & 0.502 & -0.692 & $0.093^{*}$ \\
\hline USIA & -0.282 & $0.086^{*}$ & -0.169 & 0.329 & 0.377 & 0.173 \\
\hline DIDIK & 0.505 & $0.001^{* * *}$ & 0.511 & $0.002^{* * *}$ & 0.380 & 0.124 \\
\hline UPAH & 0.226 & $0.063^{*}$ & 0.234 & $0.061^{*}$ & -0.111 & 0.517 \\
\hline JML.KEL & -0.092 & 0.674 & 0.619 & $0.008^{* * *}$ & 0.493 & 0.152 \\
\hline KAJIAN & 0.150 & $0.098^{*}$ & 0.086 & 0.362 & 0.208 & 0.126 \\
\hline P.UST & 0.071 & 0.604 & 0.234 & 0.118 & 0.237 & 0.267 \\
\hline ZAKAT & -0.098 & 0.805 & -0.120 & 0.773 & -0.129 & 0.827 \\
\hline Constant & -2.277 & 0.003 & -3.659 & 0.000 & -3.035 & 0.015 \\
\hline
\end{tabular}

Keterangan: ${ }^{*}$ signifikansi $10 \%{ }^{* *}$ signifikansi $5 \%{ }^{* * *}$ signifikansi $1 \%$

Sumber: data diolah (2020)

Hasil uji signifikansi model ketiga berbeda dengan model pertama dan kedua. Pada model ketiga, variabel pendidikan tidak mempengaruhi variabel terikatnya yaitu keputusan berwakaf uang. Tidak berpengaruhnya pendidikan mengindikasikan bahwa orang yang pendidikannya tinggi dengan pengetahuan wakaf uang yang tinggi tidak serta merta mau berwakaf uang. Keputusan seseorang mau berwakaf uang lebih ditunjukkan oleh jenis kelamin seseorang, tapi ini pun tidak dalam tingkat signifikansi yang sama melainkan hanya 90 persen saja (tidak sampai 95\%).

Hasil olah data dengan metode regresi logit, juga dikuatkan dengan hasil analisis uji koefisien kontigensi sebagaimana terlihat pada Tabel 7. Terlihat bahwa pendidikan, pekerjaan dan status dalam keluarga memiliki hubungan yang erat dengan pengetahuan seseorang terhadap wakaf uang. Sedangkan keputusan berwakaf juga berhubungan dengan pendidikan, usia, penghasilan, jumlah anggota keluarga, status dalam keluarga dan keaktivan dalam mengikuti kajian, serta ulama yang menjadi panutan. Variabel yang memiliki hubungan yang erat dengan keputusan seseorang berwakaf uang antara lain usia, pendidikan, jumlah anggota keluarga dan keaktivan dalam mengikuti kajian.

Hasil uji koefisien kontigensi hanya pendidikan yang konsisten memiliki hubungan terhadap pengetahuan tentang wakaf uang, pemahaman tentang wakaf dan keputusan berwakaf, baik itu wakaf secara umum maupun wakaf uang. Hal ini mengindikasikan bahwa individu yang memiliki pendidikan dengan tingkat yang lebih tinggi akan lebih mungkin memahami tentang wakaf dan juga memiliki pentetahuan tentang wakaf uang. Mereka yang 
memiliki pendidikan tinggi (sarjana dan pascasarjana) juga akan lebih mungkin berwakaf dibandingkan dengan mereka yang memiliki pendidikan hanya sebatas diploma atau bahkan SMA dan sederajatnya.

Keputusan berwakaf (baik wakaf uang ataupun bukan wakaf uang) memiliki hubungan yang erat dengan pengetahuan wakif terhadap wakaf uang dan kebolehan hukum wakaf uang. Hal ini menunjukkan bahwa wakif yang memiliki pengetahuan tentang wakaf uang dan kebolehan hukum wakaf uang hampir pasti telah menunaikan wakaf dalam berbagai bentuk.

Tabel 7

Output $P$-Value Koefisien Kontigensi

\begin{tabular}{lccc}
\hline \multicolumn{1}{c}{ Karakteristik } & $\begin{array}{c}\text { Pengetahuan } \\
\text { Wakaf Uang }\end{array}$ & $\begin{array}{c}\text { Keputusan } \\
\text { Berwakaf }\end{array}$ & $\begin{array}{c}\text { Keputusan } \\
\text { Berwakaf Uang }\end{array}$ \\
\hline Provinsi & $0.043^{* *}$ & 0.359 & 0.419 \\
Jenis Kelamin & 0.144 & 0.425 & 0.862 \\
Usia & 0.325 & $0.005^{* * *}$ & $0.009^{* * *}$ \\
Pendidikan & $0.001^{* * *}$ & $0.000^{* * *}$ & $0.001^{* * *}$ \\
Pekerjaan & $0.007^{* * *}$ & 0.157 & 0.296 \\
Penghasilan & 0.105 & $0.001^{* * *}$ & 0.352 \\
Status Pernikahan & 0.606 & $0.012^{* *}$ & 0.132 \\
Jumlah Anggota Keluarga & 0.727 & $0.000^{* * *}$ & $0.064^{*}$ \\
Status dalam Keluarga & $0.042^{* *}$ & $0.065^{*}$ & 0.204 \\
Frek mengikuti Kajian & 0.195 & $0.019^{* *}$ & $0.033^{* *}$ \\
Pengaruh Ulama Panutan & 0.662 & $0.055^{*}$ & 0.177 \\
Rutinitas membayar Zakat & 0.882 & 0.797 & 0.743 \\
Hukum Wakaf & & 0.762 & 0.186 \\
Pengetahuan Wakaf Uang & & $0.000^{* * *}$ & \\
Kebolehan Wakaf Uang & & $0.097^{*}$ & \\
\hline
\end{tabular}

Keterangan: * signifikansi 10\%; ${ }^{* *}$ signifikansi $5 \%$; $^{* * *}$ signifikansi $1 \%$

Sumber: data diolah (2020)

Selain memiliki kesamaan, hasil analisis data dengan metode logit dan koefisien kontigensi juga memiliki beberapa perbedaan. Usia dan pendidikan tidak memiliki pengaruh yang signifikan terhadap keputusan seseorang berwakaf uang, sedangkan pada pendekatan koefisien kontigensi keduanya memiliki hubungan yang signifikan. Meskipun hasil yang diperoleh tidak sama dalam hal signifikansinya, namum jika diamati hubungan yang terjadi antara usia dan keputusan berwakaf uang pada kedua metode relatif sama. Dimana, semakin tua seseorang maka akan semakin besar kemungkinannya berwakaf uang. Sedangkan semakin muda seseorang semakin kecil kemungkinannya berwakaf uang. Sama halnya dengan usia, pendidikan juga memiliki hubungan yang sama pada kedua metode, yaitu berhubungan positif atau berbanding lurus. Mereka yang memiliki pendidikan tinggi akan lebih mungkin berwakaf uang jika dibandingkan mereka yang memiliki pendidikan lebih rendah.

Selain usia dan pendidikan, pada hasil uji koefisien kontigensi, keaktifan seseorang dalam mengikuti kajian keislaman juga memiliki hubungan dengan keputusan seseorang 
berwakaf uang. Mereka yang sering mengikuti kajian keislaman akan lebih mungkin berwakaf uang dibandingkan dengan mereka yang jarang atau bahkan tidak pernah mengikuti kajian keislaman.

\section{SIMPULAN}

Dari berbagai karaktetistik demografis yang ada, keputusan berwakaf uang ditentukan oleh usia seseorang. Semakin berumur orang tersebut maka akan semakin tinggi peluangnya berwakaf uang. Meskipun demikian, pendidikan tetap menjadi pengaruh utama terhadap pengetahuan seseorang terhadap wakaf uang. Semakin tinggi tingkat pendidikan seseorang terhadap wakaf uang maka akan semakin tinggi pula pengetahuannya tentang wakaf uang dan pada akhirnya semakin besar pula kemungkinannya berwakaf uang. Selain usia dan pendidikan, seringnya seseorang mendatangi majelis ilmu atau aktif dalam kajian merupakan salah satu karakteristik yang memungkinkan orang tersebut berwakaf uang.

Karakteristik seseorang dari sisi pendidikan, usia dan aktivitas menuntut ilmu agama merupakan faktor utama yang menyebabkan orang tersebut berwakaf uang. Pendidikan yang semakin tinggi, usia yang semakin matang serta semakin banyaknya aktivitas yang dilakukan untuk menuntut ilmu agama menghasilkan pemahaman yang semakin tinggi. Tingginya pemahaman terhadap wakaf uang dapat menjadi landasan untuk mendorong masyarakat berperan serta aktif dalam penghimpunan dana wakaf uang. Menumbuhkan pengetahuan yang baik tentang wakaf uang dapat dilakukan mengunakan sarana pendidikan formal maupun informal. Secara formal, memasukkan pengetahuan tentang wakaf uang dalam berbagai pelajaran atau mata kuliah di perguruan tinggi selayaknya dilakukan secara terstruktur, tidak hanya sebatas himbauan saja. Pemerintah dapat memasukkan pembahasan wakaf uang ke dalam kurikulum sekolah ataupun membuka program studi wakaf atau setidaknya konsentrasi wakaf yang didalamnya banyak membahas tentang wakaf uang.

\section{DAFTAR PUSTAKA}

Adeyemi, A. A., Ismail, N. A., \& Hassan, S. S. B. (2016). An Empirical Investigation of the Determinants of Cash Waqf Awareness in Malaysia. Intellectual Discourse, 24(0).

Creswell, J. W. (2013). Research Design: Qualitative, Quantitative, and Mixed Methods Approaches, 4th Edition (4th edition). SAGE Publications, Inc.

Dahlan, R. (2015). Faktor-faktor Yang Memengaruhi Persepsi Nazhir Terhadap Wakaf Uang. Al-Iqtishad: Jurnal Ilmu Ekonomi Syariah, 6(2), 305-315.

Efrizon, A. (2008). Faktor-faktor yang Mempengaruhi Wakif Tentang Wakaf Uang [Tesis]. Universitas Indonesia.

Fahmi, A., \& Sugiarto, E. (2016). Sistem Informasi Geografis untuk Pengelolaan dan Monitoring Persebaran Aset Wakaf. Techno.Com, 15(4), 327-334.

Fanani, M. (2011). Pengelolaan Wakaf Tunai. Walisongo: Jurnal Penelitian Sosial Keagamaan, 19(1), 179-196.

Furqon, A. (2011). Analisis Praktek Perwakafan Uang pada Lembaga Keuangan Syariah. Walisongo: Jurnal Penelitian Sosial Keagamaan, 19(1), 157-178.

Ilyas, S. (2014). Perkembangan Perwakafan di Kota Batam. Jurnal Bimas Islam, 7(4), 783-795.

Kasdi, A. (2016). Pergeseran Makna dan Pemberdayaan Wakaf. ZISWAF : Jurnal Zakat Dan Wakaf, 3(1), 1-17.

Kotler, P. T., \& Keller, K. L. (2015). Marketing Management (15 edition). Pearson.

Lubis, H. (2020). Potensi dan Kendala Pengembangan Wakaf Uang di Indonesia. ISLAMIC BUSINESS and FINANCE, 1(1), 43-59. 
McMillan, J. H., \& Schumacher, S. (2009). Research in Education: Evidence-Based Inquiry (7 edition). Pearson.

Satrio, E., \& Siswantoro, D. (2016). Analisis Faktor Pendapatan, Kepercayaan Dan Religiusitas Dalam Mempengaruhi Minat Muzakki Untuk Membayar Zakat Penghasilan Melalui Lembaga Amil Zakat. Simposium Nasional Akuntansi XIX, Lampung.

Sekaran, U., \& Bougie, R. (2013). Research Methods for Business: A Skill-Building Approach (6 edition). Wiley.

Siswantoro, D., \& Rosdiana, H. (2016). Sustainability of Cash Waqf Development in Indonesia: A Quintuple Helix Perspective. Sains Humanika, 8(1-2), 111-116.

Yunimar, M. (2015). Tingkat Pemahaman Mahasiswa Universitas Islam Negeri Syarif Hidayatullah Jakarta Terhadap Wakaf Uang [Sripsi]. UIN Syarif Hidayatullah. 